Reprod. Nutr. Dévelop., 1986, 26 (1 A), 39-51.

\title{
Frequency and structure of macrophages and abnormal sperm cells in guinea fowl semen
}

\author{
R. A. HESS (1), B. L. HUGHES, R. J. THURSTON
}

Department of Poultry Science, Clemson University Clemson, South Carolina 29631.

Summary. Semen from young and old guinea fowl was examined for macrophages and abnormal sperm cells. Large numbers of macrophages were found in the semen from both groups. However, there were significantly more abnormal sperm cells in the semen of the young males. The abnormal celis consisted of large coiled cells, bent spermatozoa, and round-headed cells. The predominant abnormality in the young males was bent sperm, although their semen also contained large round cells. The large round cells were identified as abnormal spermatids by electron microscopy and were more prominent in the older males. The abnormal spermatids were pleomorphic and exhibited various stages of intermediate and late spermatid development.

The macrophages were activated cells that exhibited phagocytosis of large number of normal spermatozoa but were never observed to engulf abnormal cells. Their ultrastructure consisted of numerous lipid droplets, vesicles of ingested spermatozoa, lysosomal structures, residual bodies, and undigested remnants of spermatozoa. The presence of macrophages and abnormal spermatids in semen has been associated with lowered fertility in other species; thus, semen with exorbitant numbers of these cells should not be used for artificial insemination of the guinea fowl.

\section{Introduction.}

In males of several animal species, macrophages are found in the reproductive tract and they increase in number after vasectomy or epididymal blockage (Tingari and Lake, 1972 ; Phadke, 1975; Thurston et al., 1975 ; Alexander ant Tug, 1977 ; Aire and Heath, 1979 ; Aire and Malmquist, 1979 ; Ball and Mitchinson, 1984). Aire and Malmquist (1979) reported large numbers of macrophages in the lumen of the rete testis of the normal domestic fowl, but the normal presence of macrophages in the excurrent ducts has not been found in other species. There also have been few reports of macrophages in ejaculated semen. In the domestic fowl, macrophages were never observed beyond the proximal ductuli efferentes (Aire and Malmquist, 1979). However, abnormal

(1) Present Address: Developmental Biologv, c/o United States Environmental Protection Agency, MD-72, Research Triangle Park, NC 27711, USA.

Published with the approval of the Director, South Carolina Agricultural Experiment Station as Technical Contribution No. 2367. 
yellow turkey semen contains numerous large activated macrophages and abnormal spermatids, with the macrophages primarily phagocytosing spermatozoa (Thurston et al., 1975). A few guinea fowl males also produce semen with abnormal spermatids and macrophages (Thurston et al., 1982). The purpose of the present study was to quantitate abnormal sperm cells and macrophages in guinea fowl semen and to describe their ultrastructure.

\section{Materials and Methods.}

Semen was collected by massage from 10 young ( 8 months) and 10 older (20 months) guinea fowl that were routinely ejaculated by massage twice per week. The birds were grown in individual cages $(25.4 \times 40.6 \mathrm{~cm})$, in an opensided house with incandescent lighting (14L: 10D). They were fed a corn-soy diet with $17.2 \%$ protein and $2838 \mathrm{kcal} / \mathrm{kg}$. The spermatozoa were prepared for phase-contrast light microscopy (LM), transmission electron microscopy (TEM), and scanning electron microscopy (SEM). For cell counts, individual whole semen samples of a single collection from each male were diluted $1: 200$ (2 replications) in a $0.13 \mathrm{M}$ phosphate buffer $(\mathrm{pH} \mathrm{7.2)}$ and counted using a $16 \mathrm{X}$ objective and a hemacytometer. LM, using a yellow Wratten filter for contrast, was performed on semen diluted $1: 1$ with the phosphate buffer.

For SEM, semen was diluted $(1: 1)$ in $2 \%$ glutaraldehyde (buffered by $0.13 \mathrm{M}$ phosphate, $\mathrm{pH} 7.2$ ) fixed for $30 \mathrm{~min}$ at $22{ }^{\circ} \mathrm{C}$, then dehydrated with increasing concentrations of ethanol $(5 \mathrm{~min} / \mathrm{ea})$. Final dehydration was in $100 \%$ ethanol for $30 \mathrm{~min}$. Fixation and dehydrating solutions were changed by microcentrifugation for $0.5 \mathrm{~min}(12000 \mathrm{~g})$, aspiration of the supernatant with a Pasteur pipet, and resuspension in the subsequent solution. One drop of spermatozoa suspended in $100 \%$ ethanol was placed on a metal SEM stub, and the cells were allowed to settle for $10 \mathrm{~min}$. The excess ethanol was removed gently with Whatman No. 1 filter paper, and the samples were critical-point dried using $\mathrm{CO}_{2}$. The dried cells were sputter-coated with gold (10 $\mu \mathrm{amps}$ ) for $440 \mathrm{sec}$, and photomicrographs were made with an ETEC Autoscan.

For TEM, pooled semen was diluted $(1: 1)$ with phosphate buffer and then microcentrifuged for $0.5 \mathrm{~min}$. A portion of the cell pellet was removed with a Pasteur pipet and fixed in $2 \%$ glutaraldehyde (phosphate buffered) for 2 hrs at

FIG. 1. - Scanning EM of normal guinea fowl spermatozoa (N) abnormal sperm (A), and macrophages (M) from semen $\times 4100$.

FIG. 2-4. - Phase contrast micrographs. Normal spermatozoon in Fig. 2, round-deaded cells in Fig. 3, large round-coiled cell in Fig. 4. A, acrosome; N, nucleus; F, flagellum. Fig. $2: \times 4000$; Fig. $3: \times 4000:$ Fig. $4: \times 3400$.

FIG. 5-7. - Scanning EM of normal and abnormal sperm cells. In Fig. 5, a round-headed sperm(R) is compared to a normal spermatozoon (S). The abnormal head is bent at the nucleus (N). A, acrosome; $M$, midpiece; $F$, flagellum. The cell shown in Fig. 6 is probably the same type as the cell shown in Fig. 4, with the flagellar components $(F)$ coiled around the abnormal head $(H)$. In Fig. 7, a large abnormal cell displays the contortions that were typical of the round-coiled cells. Fig. $5: \times 3600 ;$ Fig. $6: \times 7600 ;$ Fig. $7: \times 7600$. 


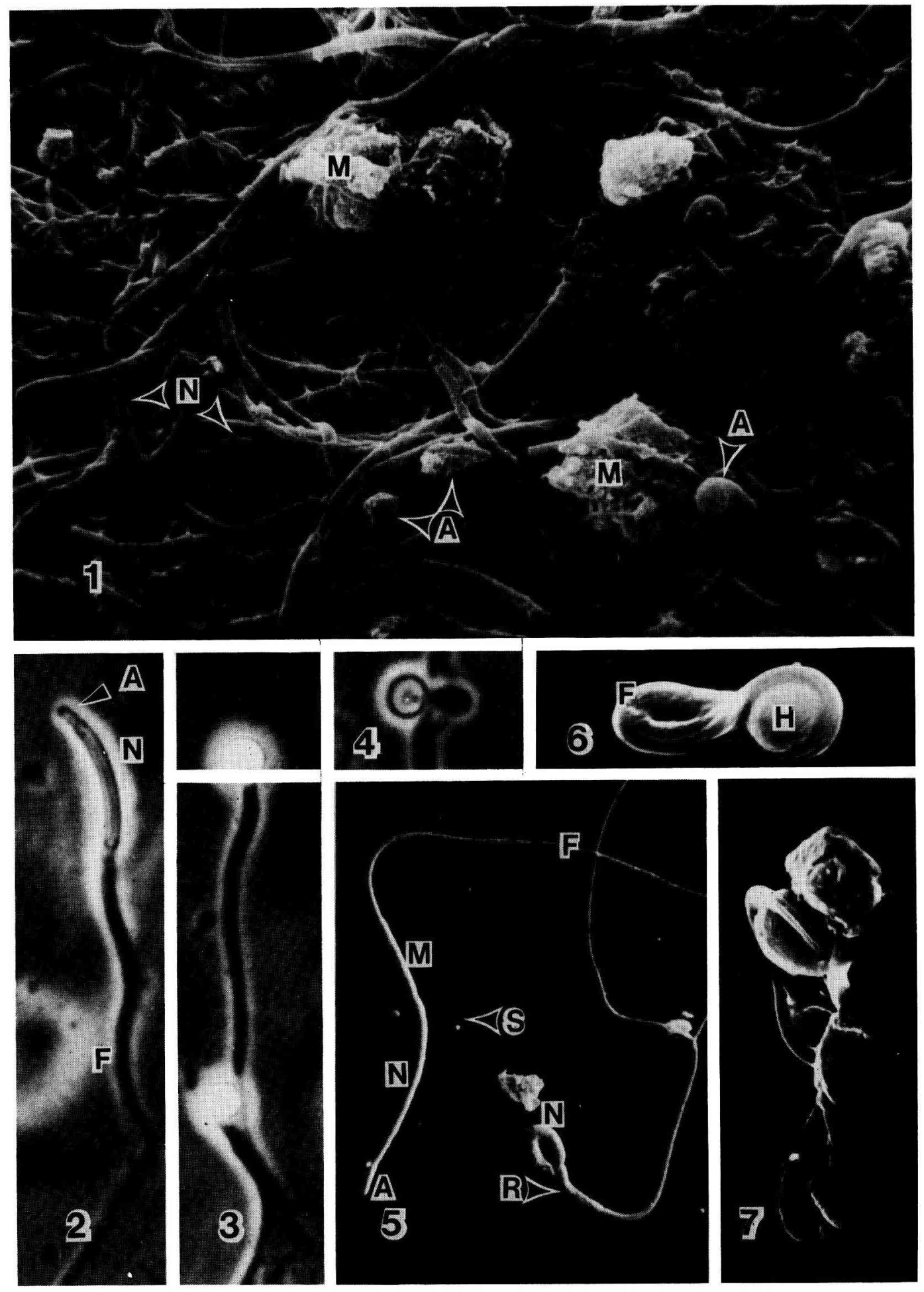


$22{ }^{\circ} \mathrm{C}$. After two buffer rinses, the cells were fixed in phosphate buffered $\mathrm{OsO} 4$ for $2 \mathrm{hrs}$ at $4^{\circ} \mathrm{C}$. Then the samples were dehydrated in a graded series of acetone solutions (35-100\%) and embedded in low-viscosity epoxy resin. Ultra-thin sections were stained with uranyl acetate and lead citrate, and photographs were made with a Philips EM300.

Cell count differences between the two age groups were determined by the Student's $t$-test $(2$ tailed) and were considered significant at $p<0.05$.

\section{Results.}

Abnormal sperm cells and macrophages in the semen of young (8 months) and old (20 months) males are compared in table 1 . The mean counts are for single ejaculations per male with 2 replications per ejaculate. The intra-ejaculate variation for all counts was between $5.3 \%$ and $9.9 \%$. Counts are expressed per milliliter because the total volume per ejaculate was small $10.1 \mathrm{ml}$ or less) and difficult to measure consistently. Although the older males had a lower number of total cells, they had the same relative number of seminal macrophages, but fewer abnormal cells than the younger males. The most obvious type of sperm abnormality was the round-headed spermatozoa (Figs. 1, 3, 5) and the large rounded and twisted cells (Figs. 4,6,7). Additionally, there were sperm bent at the midpiece or tail and coiled sperm. Although a differential count was not made, it was noted that more than $50 \%$ of the abnormal cells in the younger males were bent spermatozoa, whereas the large round or coiled cells were the predominant form in the older semen. Using phase-contrast microscopy the round-headed and coiled cells were identified by the large prominent halo surrounding the cell (Figs. 3, 4). SEM revealed that the round-headed cells were bent at the nucleus and that the twisted and coiled cells were entangled by multiple strands of flagella (Figs. 6, 7).

TABLE 1

Number of total cells, abnormal sperm cells, and macrophages in guinea fowl semen from young and old males ( ${ }^{1}$ ).

\begin{tabular}{|c|c|c|c|c|}
\hline & $\mathrm{N}$ & $\begin{array}{c}\text { Total cells per } \\
\text { ml } \\
\left(\times 10^{9}\right)\end{array}$ & $\begin{array}{l}\text { Abnormal sperm } \\
\text { cells per ml } \\
\left(\times 10^{9}\right)\end{array}$ & $\begin{array}{c}\text { Macrophages } \\
\text { per ml } \\
\left(\times 10^{7}\right)\end{array}$ \\
\hline $\begin{array}{l}\text { Young (2) } \\
\text { Old (2) }\end{array}$ & $\begin{array}{l}10 \\
10\end{array}$ & $\begin{array}{l}5.265 \pm 0.326^{\mathrm{a}} \\
3.807 \pm 0.398^{\mathrm{b}}\end{array}$ & $\begin{array}{l}1.374 \pm 0.090^{\mathrm{a}} \\
0.570 \pm 0.076^{\mathrm{b}}\end{array}$ & $\begin{array}{l}3.6 \pm 1.2^{\mathrm{a}} \\
3.0 \pm 0.6^{\mathrm{a}}\end{array}$ \\
\hline
\end{tabular}

(1) Means \pm S.E Significant differences betwen young and old are indicated by different superscripts (t-test ; $p<0.05) ;(2)$ Young $=8$ months; old $=20$ months.

FIG. 8-9. - Transmission EM of two large round-coiled abnormal spermatids. The cell in Fig. 8 is more mature, having condensed chromatin (C) and a formed acrosome (A), but it contains misaligned mitochondria (M) and excess cytoplasm encircled by the flagellum ( $F$ ). The abnormal cell in Fig. 9 is immature, with less condensed chromatin (C), incompletely formed acrosome (A), randomly scattered mitochondria $(M)$, disorganized microtubules (D), and coils of the flagellum (F). The presence of two centrioles $(\mathrm{Ct})$ attached to the nucleus is also abnormal. The small dense bodies (B) lining the nucleus are unidentified. Fig. $8: \times 31700$; Fig. $9: \times 17450$. 


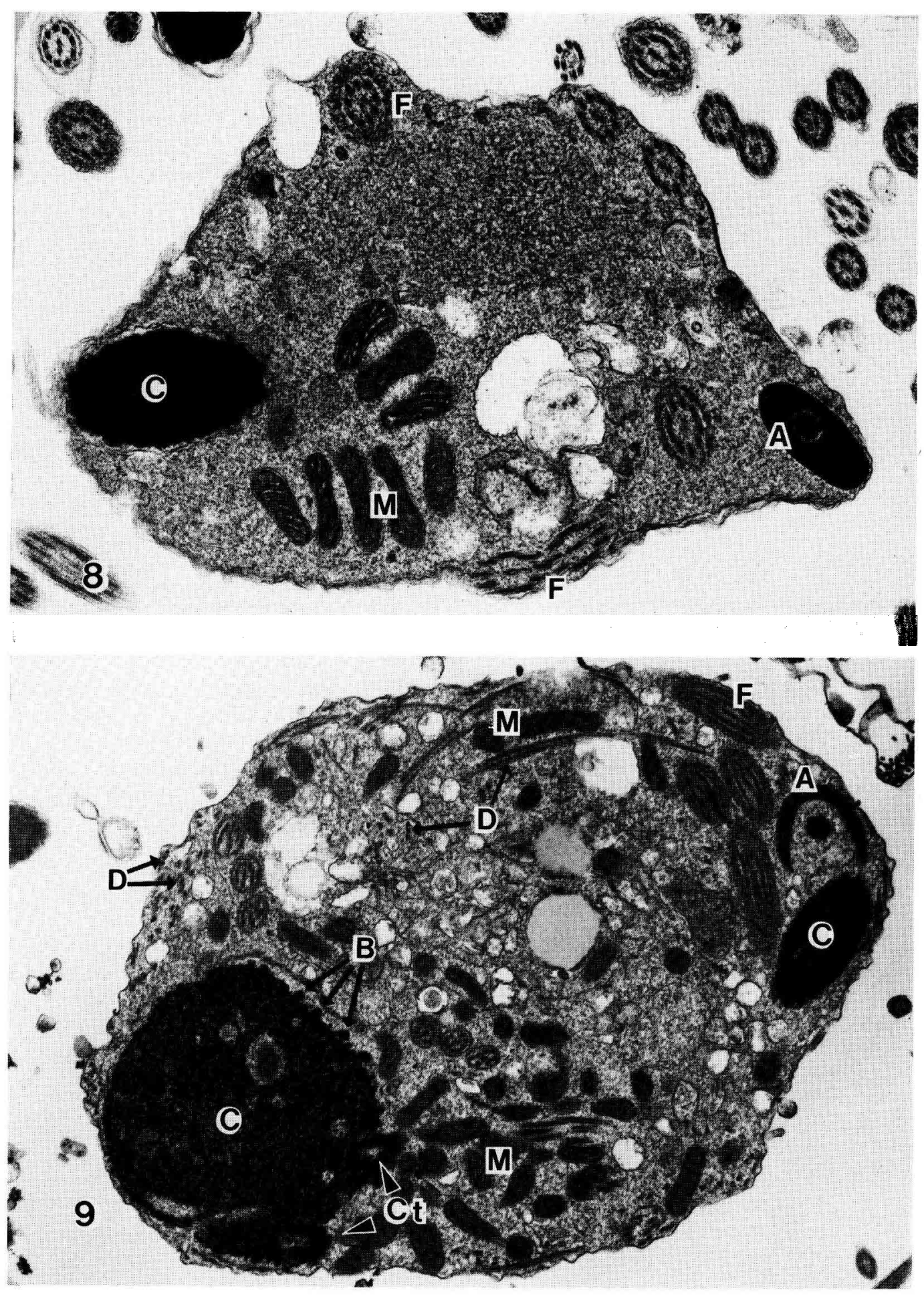


The large abnormal cells were immature, abnormal spermatids, as revealed by their complex ultrastructures. The nuclear chromatin was condensed to varying degress (Figs. 8, 9, 10, 11). The completeness of the acrosomes and the degree of organization of the mitochondria were variable. The mitochondria were frequently disorganized or scattered rather than arrayed around the axonemal complex. A consistent feature of all the large abnormal cells was that the flagella was coiled repeatedly at the periphery of the cytoplasm. Various arrays of membranous material were often seen in the cytoplasm (Figs. 10, 11) in the form of swirls, vesicles, and annulate lamellae.

The macrophages were identified by phase-contrast microscopy as large refractive cells, and SEM showed that they bound spermatozoa to their cell surface (Fig. 1). By TEM the macrophages were shown to be mononuclear, activated cells often as large as $6 \mu \mathrm{m}$ in diameter. They appeared to phagocytose a large number of morphologically normal spermatozoa (Fig. 12). There was no evidence of selective binding or engulfment of the abnormal spermatids. The cytoplasm of the macrophages was typical of phagocytic cells and contained, in addition to vesicles filled with parts of spermatozoa, numerous lipid droplets, lysosomal structures, large residual-digestive bodies, and remnants of undigested components of spermatozoa (Figs. 12-16).

There appeared to be a sequence to the phagocytosis resulting ultimately in the digestion of the spermatozoa. The initial event was the binding of the sperm cells to the pseudopodia that were extended by the macrophages (Figs. 13, 14). Only sperm heads, including the acrosomes and nuclei, were seen attached to the cytoplasmic extensions. After attachment, the sperm were surrounded by cytoplasm, forming a vesicle in which digestion could take place (Fig. 14). Resistant structures, e.g., microtubules and membranes, were sequestered in large vesicles for digestion (Fig. 15) or they were discharged into the semen, as microtubules were seen in the plasma portion (Fig. 12). Finally, large residual bodies accumulated in the macrophages (Fig. 16).

\section{Discussion.}

Semen from young and old guinea fowl contained numerous mononuclear phagocytes that were engulfing and digesting large numbers of morphologically normal spermatozoa. In addition, numerous abnormal sperm cells were found in guinea fowl semen. The most obvious cells were large round, abnormal spermatids, which exhibited various contortions and coiling. Although more of the large round spermatids were found in the semen of the older males, they were

FIG. 10-11. - Transmission EM of two large, possibly coiled abnormal late-spermatids. The cell in Fig. 10 contains an annulate lamellae (A), which consists of stacks of fenestrated membranes in the cytoplasm. N, nucleus; $M$, mitochondria ; $F$, flagellum. The cell in Fig. 11 exhibits a crosssection of what appears to be the midpiece with alignment* of the mitochondria (M), but it is contained in excess cytoplasm in which membraneous swirls (S) are abundant. The small densebodies (B) are unidentified, but are also seen in Fig. 9 surrounding the nucleus. Numerous flagellar cross-sections (F) are found in the cytoplasm. Fig. $10: \times 21500 ;$ Fig. $11: \times 26300$. 


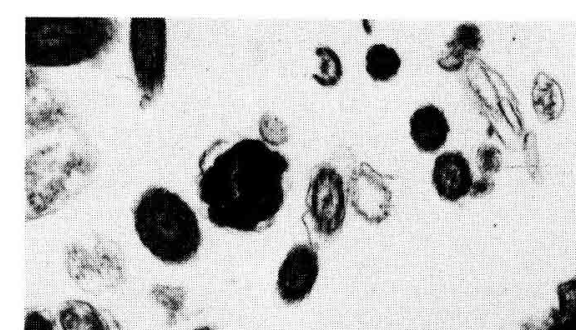

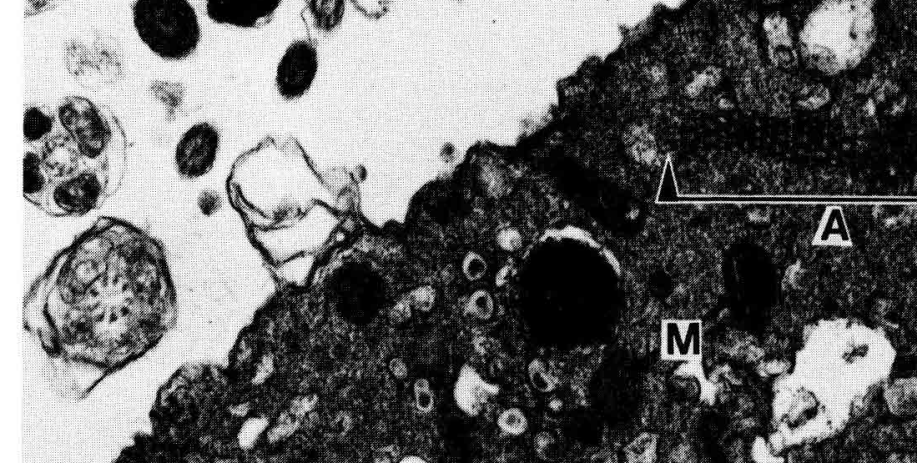

- H. 18 ol
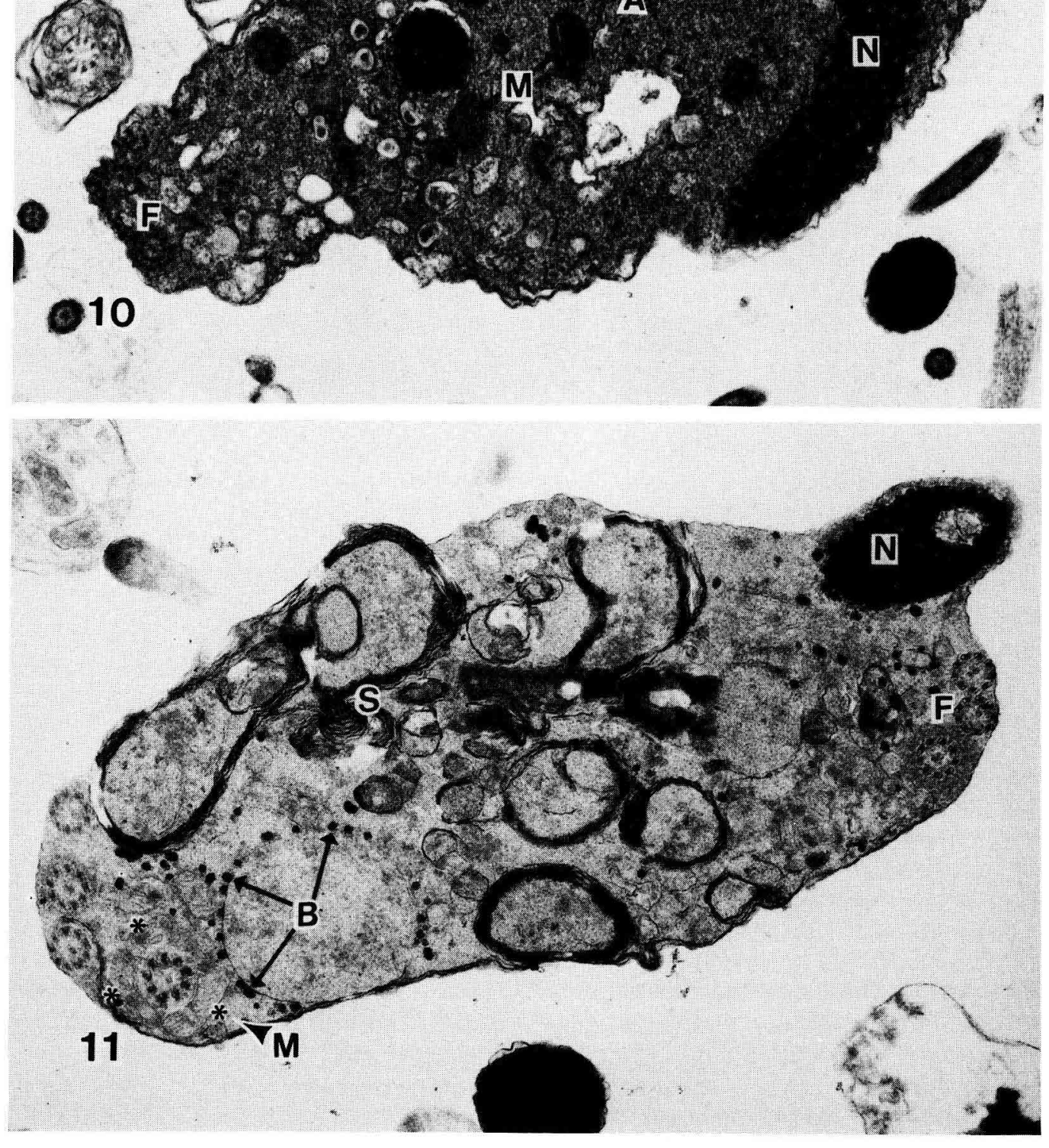
also present in semen from the younger males. However, the younger males had a greater total number of abnormal cells, with the bent spermatozoa being the most prominent. The presence of macrophages and abnormal-round spermatids in semen is identical to the cytological pattern of the yellow semen syndrome that is common among turkeys (Thurston et al., 1975), and the abnormal spermatids resemble those reported in a case of human infertility (Sun and White, 1979). The cause of such anomalies is unknown.

Gonadal regression may be one cause of macrophages and spermatids in the semen. In this study, the older males were thought to be in a state of reproductive decline, especially since there was a decrease in sperm concentration and the presence of both macrophages and abnormal spermatids. The development of the spermatids appeared to be interrupted between steps 5 and 7 of spermiogenesis (Aire et al., 1980), but with certain cellular components, such as the flagellum, continuing to develop in an uncontrolled manner. The spermatids were pleomorphic, some being mature with highly condensed chromatin and fully developed acrosomes, while others were immature. In the regressed testis of the guinea fowl (Barbier and Leroy, 1970) and the swan (Breucker, 1978), incompletely developed spermatids are found in the lumen of the seminiferous tubules. Thus, it would be expected that such cells would be found in the semen during the decline in reproductive function. In young males these cells must be the results of other mechanisms. Parvinen and Ruokonen (1982) have shown that Sertoli cells exhibit functional differences at various stages of spermatogenesis corresponding to specific levels of testosterone. Therefore, seminiferous tubules may show local dysfunction and release of immature spermatids due to a local hormonal imbalance. The fact that annulate lamellae were found in the immature spermatids supports this hypothesis, because hyperestrogenism and low androgen have been associated with the presence of these membranous structures in the cytoplasm (Kessel, 1983).

In mammals, the Sertoli cell is responsible for the disposal of excess cytoplasm that is not used in the formation of spermatozoa (Russel, 1977). The mechanism involves «tubulobulbar complexes", which are cytoplasmic extensions of spermatids into the Sertoli cell, and subsequent degradation by lysosomes (Russell, 1980). It is not known if avian testes contain such a mechanism (Okamura and Nishiyama, 1976), but a disturbance of this system in mammals causes the release of abnormal spermatids. Russell (1980) found that implanted testosterone in hypophysectomized rats prevented the tubulobulbar complex from forming, leaving cytoplasm around the head and tail of the spermatids, in the hamster, Gravis (1980) found that dibutyryl cyclic AMP caused a similar problem, resulting in the inhibition of spermiation. Thus, the formation of

FIG. 12. - Transmission EM of a seminal macrophage that has phagocytosed numerous normal spermatozoa. N, macrophage nucleus ; S, spermatozoa nuclei ; A, acrosomes ; L, lysosomal bodies. Note the cellular debris (D) and microtubules (M) surrounding the macrophage, probably the remnants of the digestive process. Also note the numerous lipid droplets (clear spaces) characteristic of these cells. $\times 8400$. 


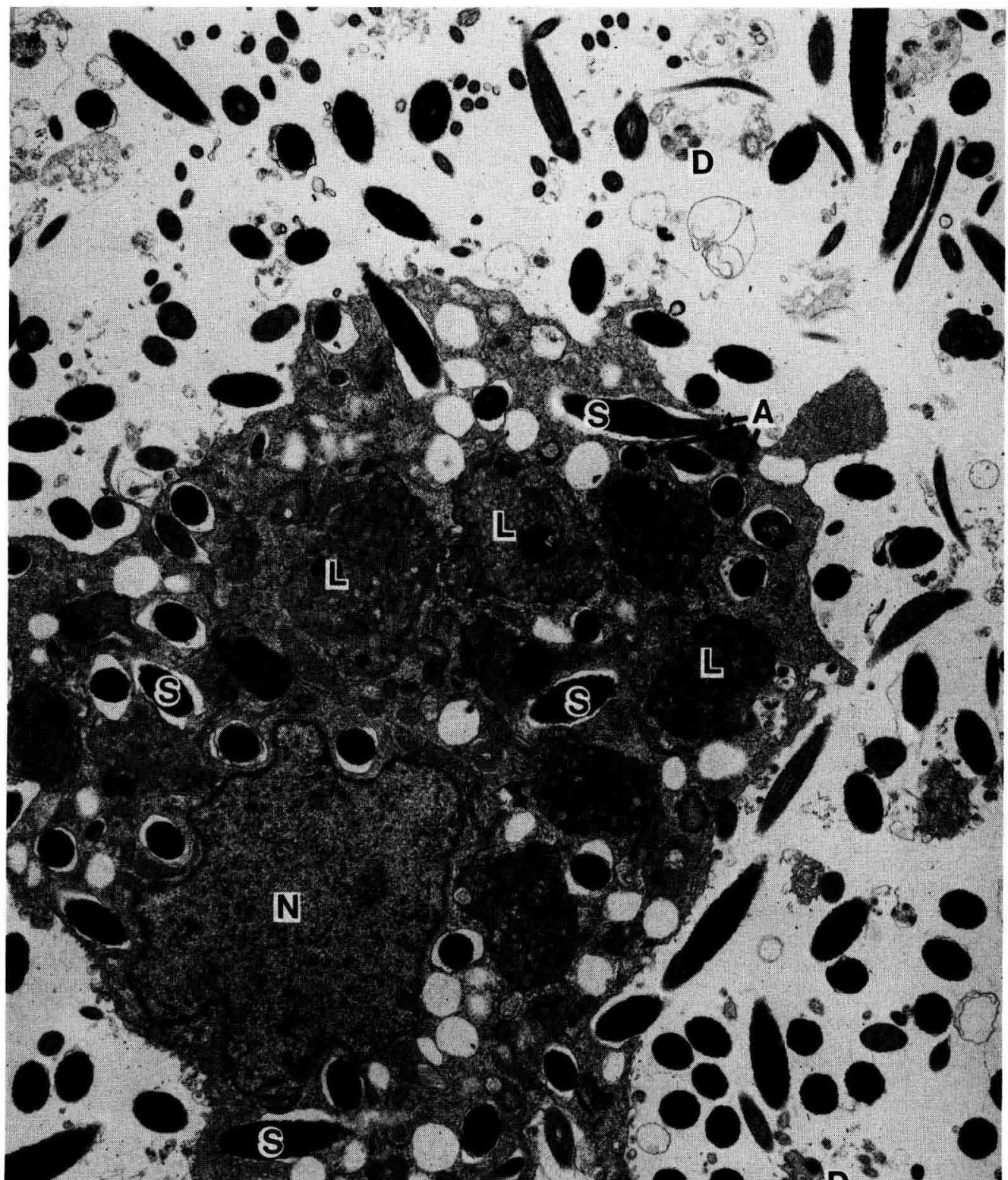

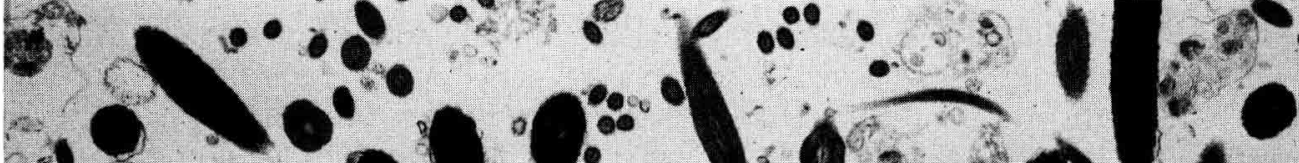

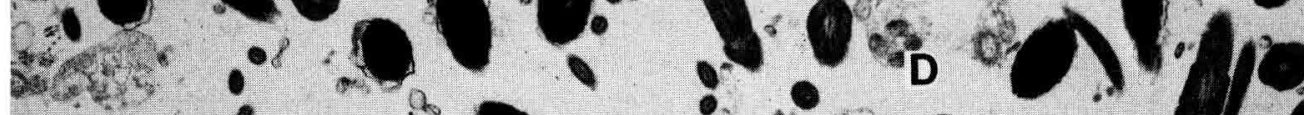

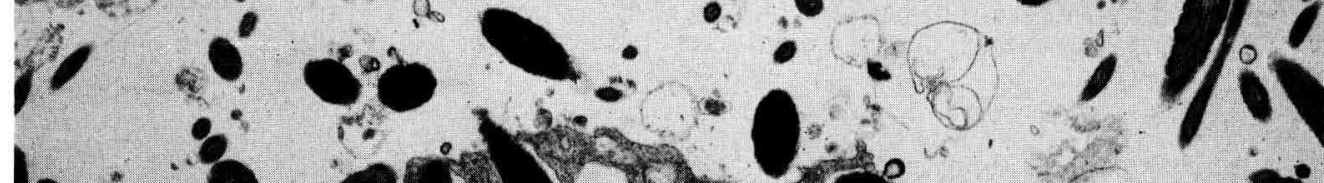

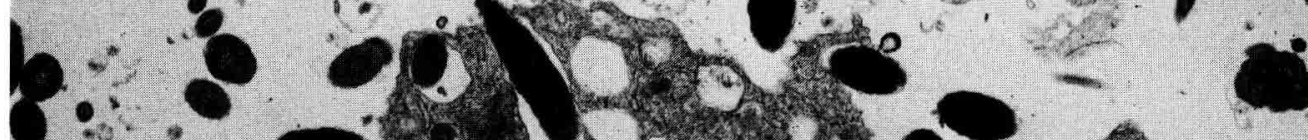
? 367.365 $00^{\circ}: t_{L}$ (ब) 
abnormal spermatids could result from deviant function of the Sertoli cells in both young and old males.

The seminal macrophages were similar in structure and phagocytic activity to those reported in the semen of turkeys (Marquez and Ogasawara, 1975 ; Thurston et al., 1975). Their ultrastructure was similar to that of macrophages in the rete testis of the domestic fowl (Aire and Malmquist, 1979), except that the nucleus was larger in the guinea fowl and the macrophages had phagocytized a greater number of spermatozoa. The ultrastructure of the nucleus in guinea fowl macrophages also was different from the macrophages in the semen and epididymis of humans and monkeys (Alexander, 1972; Phadke, 1975). The phagocytic process appeared to be the same as reported for the phagocytosis of spermatozoa by mouse peritoneal macrophages (Ball and Mitchinson, 1977), which bind the head region first, form phagocytic vesicles, and accumulate residual bodies and undigested microtubules and nuclear material (Ball et al., 1984). However, the phatocytic activity was not directed toward the abnormal spermatids. Instead, the macrophages were observed to bind large numbers of normal spermatozoa. This activity could reduce the total number of cells per ejaculate. It is possible that the retention of semen in the excurrent ducts for long intervals could cause an increase in the rate of phagocytosis, as macrophages are exposed to older semen. This problem was not addressed in this study ; however, the males were routinely ejaculated twice per week. Phagocytosis of morphologically normal spermatozoa has also been found in the turkey (Marquez and Ogasawara, 175 ; Thurston et al., 1975) and in man (Phadke, 1975).

This study has shown the presence of macrophages and abnormal spermatids and spermatozoa in the semen from young and old guinea fowl. In other species (Thurston et al., 1975 ; Sun and White, 1979), these cell types are associated with lowered fertility; thus, their potential deleterious effects should be considered in the evaluation of guinea fowl semen.

Reçu en mai 1985.

Accepté en octobre 1985.

Résumé. Fréquence et structure des macrophages et des cellules spermatiques anormales dans le sperme de pintadeau.

Les macrophages et les cellules spermatiques anormales ont été recherchés dans le sperme de pintadeaux jeunes et âgés. De grandes quantités de macrophages ont été trouvées dans le sperme des deux groupes. Cependant, il y avait significativement plus de

FIG. 13-16. - Transmission EM of the phagocytic processes seen in active macrophages of guinea fow/ semen. The initial step is the contact with the nucleus or head region of the spermatozoon (S) and extension of a pseudopodium (P), as seen in Fig. 13. A phagocytic vesicle (V) is formed once the pseudopodium (P) has completely surrounded the sperm cells (Fig. 14). In Fig. 15 the more resistant components, microtubules and membranes (M), are sequestered in large vesicles for further digestion or discharge into the semen. Numerous lysosomal structures (L) and residual bodies with pigments ( $\mathrm{Rb}$ ) accumulate in the cytoplasm as the macrophage actively digests the spermatozoa (Fig. 16). Fig. 13: × $12400 ;$ Fig. 14: × $22200 ;$ Fig. 15: $\times 7350 ;$ Fig. 16: $\times 15730$. 


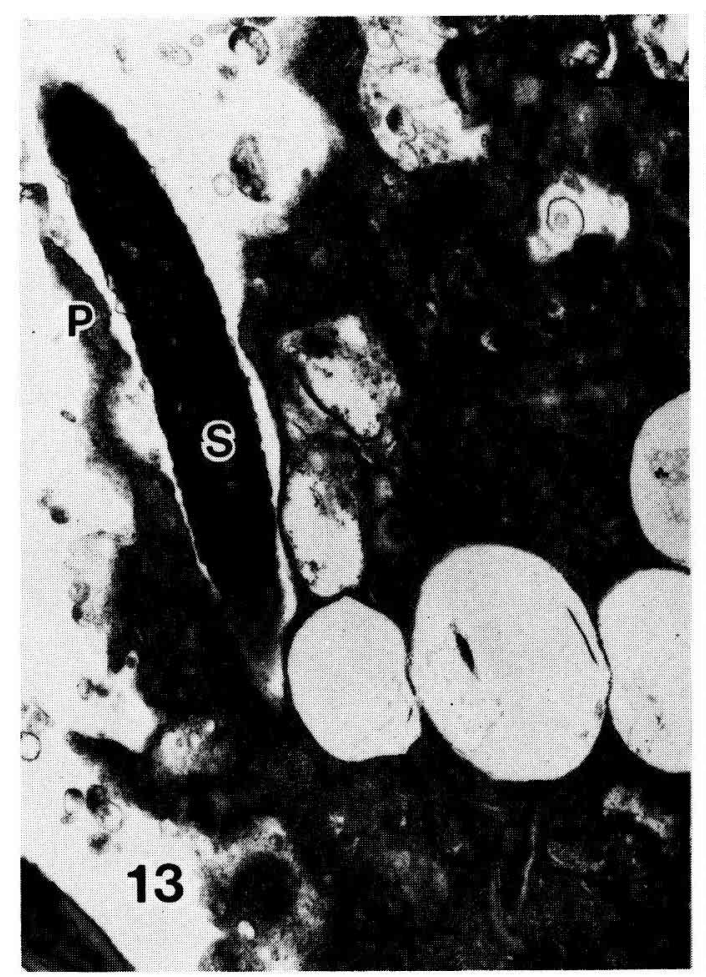

)
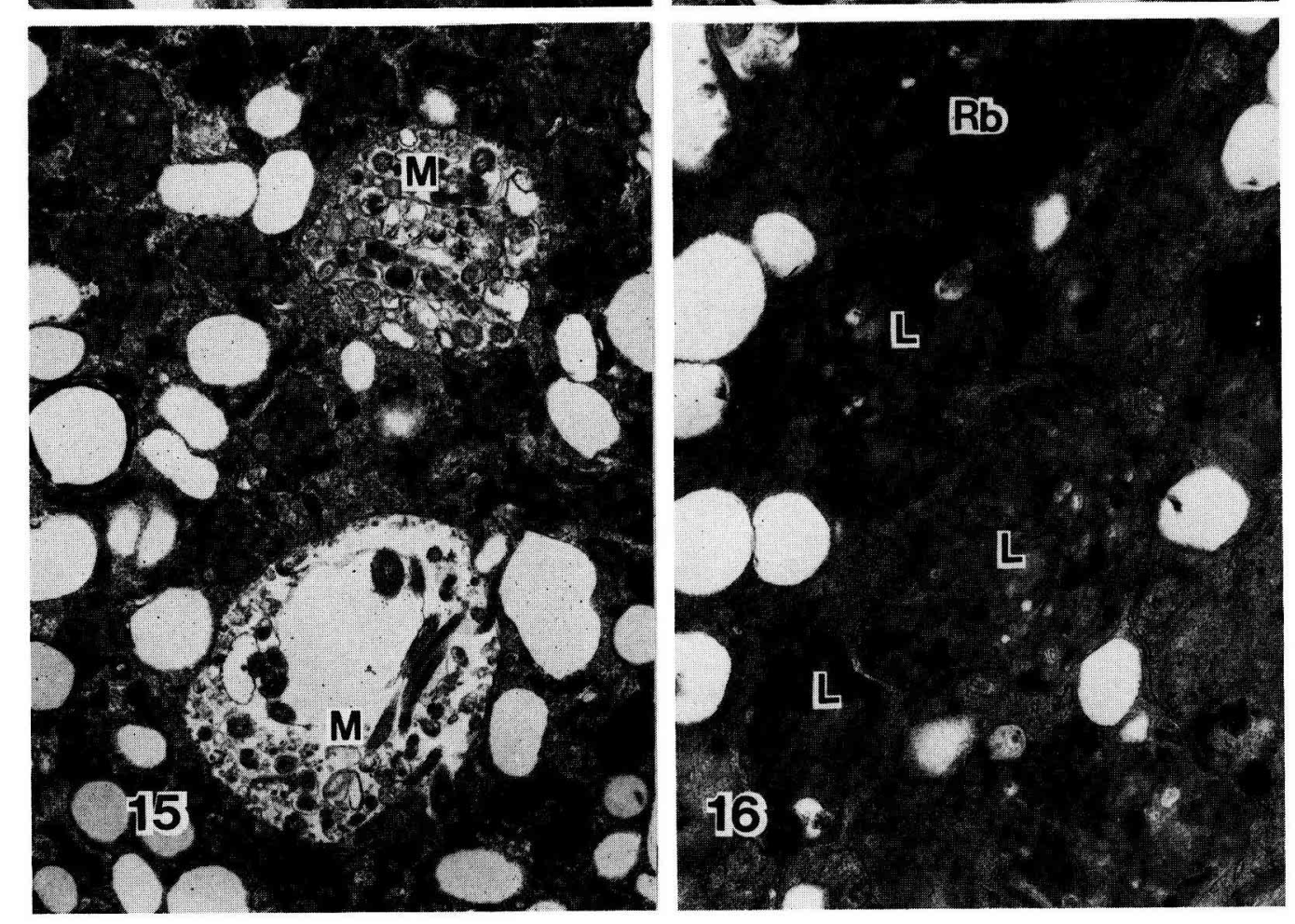
cellules spermatiques anormales dans le sperme des jeunes mâles. Les cellules anormales comportaient des grandes cellules rondes-spiralées, des spermatozoïdes courbés et des cellules à tête ronde. Le défaut prédominant chez les jeunes mâles était le spermatozoïde courbé ; leur sperme comportait aussi de grandes cellules rondes. Par microscopie électronique, on a identifié les grandes cellules rondes comme étant des spermatides anormaux; celles-ci étaient plus nombreuses chez les mâles âgés. Les spermatides anormaux étaient pléomorphiques et étaient arrivés à divers stades intermédiaires et avancés de développement spermatique.

Les macrophages étaient des cellules actives qui avaient phagocyté un grand nombre de spermatozoïdes normaux, mais apparemment pas de cellule anormale. Leur ultrastructure consistait en de nombreuses gouttelettes lipidiques, de vésicules contenant des spermatozoïdes ingérés, des structures lysosomiques, des corps résiduels et des restes de spermatozoïdes non digérés. La présence d'une quantité excessive de macrophages et de spermatides est anormale et le sperme contenant une quantité excessive de ces cellules doit être éliminé avant l'insémination artificielle des pintades.

\section{Références}

AIRE T. A., HEATH E. H., 1979. Long-term vasoligation in the domestic fowl (Gallus domesticus). Res. vet Sci, 26, 277-283.

AIRE T. A., MALMQUIST M., 1979. Macrophages in the excurrents ducts of the testes of normal domestic fowl (Gallus domesticus). Zbl. vet. Med. C. Anat. Histol. Embryol., 8. 172-176.

AIRE T. A., OLOWO-OKORUN M. O. AYENI J. S., 1980. The seminiferous epithelium in the guinea fowl (Numida meleagris). Cell Tiss. Res., 205, 319-325.

ALEXANDER N. J., 1972. Vasectomy : long-term effects in the rhesus monkey. J. Reprod. Fertil., 31, 399-406.

ALEXANDER N. J., TUNG K. S. K., 1977. Immunological and morphological effects of vasectomy in the rabbit. Anat. Rec., 188, 339-350.

BALL R. Y., MITCHINSON M. J., 1977. Degradation of phagocytosed spermatozoa by mouse peritoneal macrophages in vitro. J. Reprod. Fertil., 49, 409-411.

BALL R. Y., MITCHINSON, M. J., 1984. Obstructive lesions of the genital tract in men. J. Reprod. Fertil., 70, 667-673.

BALL R. Y., SCOTT N., MITCHINSON M. J., 1984. Further observations on spermiophagy by murine peritoneal macrophages in vitro. J. Reprod. Fertil., 71, 226.

BARBIER Y., LEROY P., 1970. Cycle annuel du testicule de la pintade. Bull. Biol., 104, 119-147.

BREUCKER H., 1978. Macrophages, a normal component is seasonally involuting testes of the swan. Cygnus olor. Cell Tiss. Res., 193, 463-471.

GRAVIS C. J., 1980. Ultrastructural observation on spermatozoa retained within the seminiferous epithelium after treatment with dibutyryl cyclic AMP. Tiss. Cell., 12, 309-322.

KESSEL R. G., 1983. The structure and function of annulate lamellae: porous cytoplasmic and intranuclear membranes. Int. Rev. Cytol., 82, 181-303.

MARQUEZ B. J., OGASAWARA F. X., 1975. Scanning electron microscope studies of turkey semen. Poult. Sci., 54, 1139-1143.

OKAMURA F., NISHIYAMA H., 1976. The early development of the tail and the transformation of the shape of the nucleus of the spermatid of the domestic fowl. Gallus gallus. Cell Tiss. Res., 169, 345-359.

PARVINEN M., RUOKONEN A., 1982. Endogenous steroids in the rat seminiferous tubules. Comparison of the stages of the epithelial cycle isolated by transillumination-assisted microdissection. J. Androl., 3, 211-220.

PHADKE A. M., 1975. Spermiophage cells in man. Fertil. Steril., 26, 760-774.

RUSSELL L. D., 1977. Spermatid-Sertoli tubulobulbar complexes as devices for elimination of cytoplasm from the head region of late spermatids of the rat. Anat. Rec., 194, 233-246. 
RUSSELL L. D., 1980. Deformities in the head region of late spermatids of hypophysectomizedhormone-treated rats. Anat. Rec., 197, 21-31.

SUN C. N., WHITE H. J., 1979. The variety of abnormal spermatozoa from patients with fertility problems, an ultrastructural study II. Immature forms. Cytologia., 44, 215-220.

THURSTON R. J., HESS R. A., BIELLIER H. V., ADLDINGER H. K., SOLORZANO R. F., 1975. Ultrastructural studies of semen abnormalities and herpesvirus associated with cultured testicular cells from domestic turkeys. J. Reprod. Fertil., 45, 235-241.

THURSTON R. J., HESS R. A., HUGHES B. L., FROMAN D. P., 1982. Uitrastructure of the guinea fowl (Numidia meleagris) spermatozoon. Poult. Sci, 61, 1738-1743.

TINGARI M. D., LAKE P. E., 1972. Ultrastructural evidence for resorption of spermatozoa and testicular fluid in the excurrent ducts of the testes of the domestic fowl, Gallus domesticus. J. Repriod. Fertil., 31, 373-381. 